SALUD

Ciencias sociales

HUMANIDADES

TEMA DEL DÍA

PENSAMENT ACTUAL

EL CEREBRO EMOCIONAL- JOSÉ LÁZARO

DÍGAME LA VERDAD, DR.-JUAN CARLOS HERNÁNDEZ-CLEMENTE

ARTE, SALUD Y SOCIEDAD

SERENDIPIA - JESUS SUEIRO JUSTEL 


\section{Co-directores}

Marc Antoni Broggi i Trias (PCBC)

Francesc Borrell (UB)

Jefa de Redacción

Núria Estrach (UAB)

\section{Consejo científico}

Juan Carlos Hernández Clemente

Juan Medrano Albéniz

Vicente Morales Hidalgo

\section{Correspondencia}

Web:

http://www.fundacionletamendi.com

Correo electrónico:

info@fundacionletamendi.com

Envío de manuscritos:

http://www.fundacionletamendi.com/revista-foliahumanistica/envio-de-manuscritos/

\begin{abstract}
Información editorial
Folia Humanística publica artículos por encargo solicitados a especialistas, así como aquellas propuestas enviadas por los autores y aceptadas tras su evaluación por pares de académicos especializados.

Los textos recibidos se publicaran en la lengua original (castellano, catalán, inglés y francés); los que se consideren de relevancia mayor serán traducidos al inglés y castellano.

Los artículos deben ser originales y acompañados del documento "derechos de autor" que encontrarán en la web, junto a las normas de presentación a seguir.

Cada artículo publicado al final tendrá especificado la referencia de citación, donde se incluirá el número DOI ${ }^{\circledR}$.

\section{Distribución \\ La Revista Folia Humanística es de libre acceso a consultar online. \\ http://www.fundacionletamendi.com/category/rev istal}

Folia Humanística es una revista internacional que tiene el doble objetivo de fomentar, por un lado, la reflexión y el debate público en el ámbito de la Salud, Ciencias Sociales y Humanidades, y por el otro, la colaboración entre distintos equipos de investigación nacionales e internacionales que dinamicen el diálogo entre la filosofía de la medicina, la salud pública y la justicia social. Dividida en "Tema del día", (artículos para el debate), "Pensamiento actual", (artículos críticos de novedades editoriales), y "Arte, Salud y Sociedad", la revista se esfuerza en fortalecer las conexiones entre la investigación académica, la práctica clínica, las experiencias de los pacientes y sus implicaciones éticas y estéticas en la sociedad. Todo ello con la intención de favorecer la reflexión entre diferentes disciplinas sobre temas de actualidad y las tendencias más novedosas en el campo de las Humanidades y la Salud.

Folia Humanística is an International Journal, born with the dual aim of fuelling the discussion and public debate on issues of health, social sciences and humanities and on the hand, of fostering cooperation between various research groups, both national and International, to spur the dialogue between philosophy and medicine, public health and social justice. The Journal is divided into three different sections: "main focus" (article for debate), "Contemporary thought" (critical reviews of new Publications) and "Arts, Health and Society" which all contribute to strengthening the links between academic research, clinical practice, the experience of patients and their ethical and esthetical implications for society. Ultimately, the intention of the Journal is to promote reflection at the crossroads of several disciplines on topical issues and new trends in humanities and health. 


\title{
SHARED MIND
}

\section{Ronald M. Epstein MD}

\begin{abstract}
Important health decisions are rarely made alone. Shared mind comes into play when clinicians and patients confront complex situations that require synthesis of facts, experiences, values and preferences. While social psychologists have described how individuals behave and interact when making group decisions, only recently has psychology considered not just individual behaviors but how their minds interact. The purpose of this article is to approach the process of shared decisions from the perspective of the patient
\end{abstract}

Key words: Shared mind; Mindfulness; Patient Autonomy; Clinical Interview; PhysicianPatient Communication

Artículo recibido: 28 de marzo 2017; aceptado: 1 junio 2017.

Last week, a robust 80-year old man came into the office whose blood sugar - and glycated hemoglobin - had been slowly worsening for several years. He was transitioning from pre-diabetes to diabetes. We were on the fence about whether he should be treated with medication. The alternative would be to tolerate his glucose intolerance without intervening, at least not yet. He exercises, but not enough. $\mathrm{He}$ has a weakness for cookies. He gave up smoking years ago. A retired engineer, he wanted the unique best solution. Yet the clinical evidence to guide the decision was not strong.

The same day I saw a 63 year old woman with a rare form of thyroid cancer and an intracardiac metastasis. Metastases in other parts of his body appeared to respond to the most recent of three chemotherapy regimens, but the intracardiac mass continued to grow. Therapeutic options ranging from best supportive care to aggressive chemoradiation were tossed about. The tumor was sufficiently rare that no one knew whether it would respond to radiation, chemotherapy, immunotherapy, or nothing. An insurance broker, she knew about probabilities, risk, uncertainty-and bargaining. 
These two situations are at one end of a spectrum from simple to complex. ${ }^{1}$ Simple situations, like an uncomplicated urinary infection, require basic knowledge and little ambiguity. Complicated situations, such as deciding between percutaneous and medical treatment for heart disease, involve expert knowledge and skill, and decisions are based on best evidence. In contrast, complex situations, such as the ones described above, are ambiguous and uncertain, the multiple factors affecting outcomes cannot be fully characterized and the outcomes are far from predictable. Think of child-rearing. The same parents in the same circumstances using the same parenting techniques would be foolish to think that each child will turn out identical, or even nearly so, even with identical twins.

Clinicians are taught to manage simple and complicated situations, but are often left to discover ways of handling complexity on their own-situations in which clinical evidence, knowledge and skill are insufficient, where patient preferences and clinical experience hold greater sway. Rather than a clear and predictable course, clinicians muddle through, the goal only coming into focus after they've embarked on the path.

Knowledge about how people manage complexity is growing through the application of social neuroscience research, which suggests ways in which thoughts, feelings and problem-solving processes are shared between two or more people. While social psychologists have described how individuals behave and interact when making group decisions, only recently has psychology has considered not just individual behaviors but how their minds interact. This line of research required looking squarely at how "mind" might even be defined. This is anything but straightforward. Mind is not merely in the head, limited to the activity of the brain; extended mind refers to the neural connections of the brain to the gut, the immune system and the HPA axis that all comprise what each of us calls "me." More recently, cognitive scientists and philosophers have considered the idea that mind is fundamentally non-local; for example, social relationships affect the expression of genes that regulate the number and type of neurotransmitter receptors in the brain, 
which in turn affect our affective responsiveness to others. Taking this view, our minds are not completely our own.

Early studies relating to shared mind were with older adult couples, noting that when one has mild cognitive impairment, the other not only compensates for the impairment, he or she actually engages in collaborative cognition, in which the boundaries in thinking processes is fluid - sometimes to the point that it can be difficult to say whether an idea has emerged from one person, the other, or the "space" between. ${ }^{2,3}$ It seemed that there were three minds present - each person's individual mind and also a shared mind not fully owned by either. Lest this sound like science-fiction, social neuropsychologists now suggest that this kind of "mind-meld" is the norm. As social beings, humans have always had to have the ability to discern the intentions of others, at the very least to infer whether the interaction will be cooperative or threatening. The idea of shared mind builds on the notion - that there is always "me" and "you" and "we." Psychiatrist Dan Siegel calls this blurred identity "mwe" (in Castellano, perhaps "yosotros").

Shared mind comes into play when clinicians and patients confront complex situations that require synthesis of facts, experiences, values and preferences. ${ }^{4-6}$ Clinicians, for example, make assumptions about the needs and intentions of patients, and we generally feel that we can read these reasonably well. Unfortunately, the literature indicates otherwise; we often don't know unless we create space in which patients can articulate their concerns and physicians can check out with the patient whether they've understood correctly. Consider the assessment of pain; clinicians' assessments often are no better than chance. The same is true about wishes about end of life care; we are correct only a bit more than half of the time. Shared mind applies to more than just the patient-clinician dyad. Similar dynamics exist even among family members who claim to know each other well.

Shared mind is a naturally occurring phenomenon. Important health decisions are rarely made alone, and can benefit from psychological and cognitive 
processing with others who have the patient's best interests at heart and have the communication skills and curiosity to inquire into the patient's needs, values and preferences. Social psychologists teach us that preferences - especially about lifeand-death matters-can be remarkably unstable, especially when patients confront unfamiliar and unanticipated choices. ${ }^{7}$ Consider the relatively common scenario of deciding whether to have disfiguring surgery for a cancer that is likely-but not definitely-incurable. Small details or the way the decision is framed can influence the choice. Most importantly, when we are ill, we are often diminished cognitively. Research indicates that people have difficulty assimilating information, become more concrete in their reasoning, don't appreciate nuance, avoid ambiguity and feel more anxious when presented with uncertainty.

Shared mind is more than sharing of knowledge and problem-solving; it involves shared physical and affective experience. When finishing with a visit, I often walk with a patient to the reception desk to check out. Although I don't consciously set out to do this, I find myself walking at the patient's pace, which can be quite slow in some cases. This not only allows for conversation (compared, say, were I to walk at my usual fast pace). My choice to walk slowly is an enactment of bodily empathy, a physical manifestation of a shared psychological connection.

Sharing of emotions, often referred to as resonance (if non-specific) or attunement (if more specific to that individual), is a component of shared mind. ${ }^{8}$ Whether the emotion is positive-a sense of caring, comfort, compassion, and camaraderie - or unpleasant, such as shared frustration or conflict, shared mind in the emotional sphere always involves some degree of analogy between mental activity in one's brain and mental activity in another's-mental cooperation, perhaps. Functional neuroimaging studies provide some support for a neural basis for attunement; when two people are engaged in cooperative tasks, the same areas of their brains are activated, in contrast to when the tasks are competitive or unrelated. The sense of trust that emerges from well-functioning patient-clinician relationships is likely related to attunement, perhaps even more so than cognitive understanding. Collaborative cognition and attunement are both necessary for collective problem- 
solving; two parties can share informational resources but will not solve problems effectively if trust is absent, at least in clinical situations in which consensus is more desirable than a negotiated settlement. The communication that supports shared mind, thus, must be informational and connexional; both parties need to know and feel known, understand and feel understood.

Shared mind offers the potential for enhancing patient autonomy through the sharing of cognitive and emotional processes, enriching the number and types of options, and achieving clarity through dialogue and support. Yet, the ethical and moral implications of shared mind have only recently been explored..$^{9}$ Ideally, shared mind should lead to wiser decisions owing to shared-and presumably enhancedcognitive resources. While autonomy has historically been considered as a quality of individual humans, free from external influence, not collectives, here, autonomy is redefined as a quality of individuals-in-relation, and the relationships serve to clarify and enact goals that may not have been apparent to the patient alone with a more limited set of cognitive and affective resources.

The idea of shared mind also suggests that identities, values, and preferences are constructed relationally. This rings true for me; we tend to adopt the norms of those who are around us. But if individual values and preferences are constructed in the moment rather than enduring attitudes of an individual, as psychologist Ellen Peters suggests, ${ }^{7}$ the potential looms for conflating the interests of a well-intentioned or not-so-well-intentioned other (family member or health care professional) with those of the patient, and in the case of the seriously ill patient, pseudo-surrogacy. ${ }^{10}$ Furthermore, patients, like all humans, may inhabit different identities depending on the situation; in the case of someone with a life-threatening illness, a given individual could express her "fight to the finish" identity or her "seeking comfort" identity. ${ }^{11}$ Here, effective communication is key, especially communication which does not try to resolve ambiguity too soon and allows for the richness of each human being to emerge. 
Cultivating shared mind involves developing well-honed communication skills, including non-verbal skills such as the use of silence. Recently, our group did a study of silences in patient-physician interactions, and were able to identify silences that represented distractions, awkward moments, and expectancy, as well as lesscommon "eloquent" silences that represented moments of deep connection, often at a poignant moment in an encounter. ${ }^{12}$ Shared mind requires self-other differentiation-feeling and witnessing another's presence while also maintaining awareness of boundaries, "de-centering"-the ability to see oneself from the outside, and empathy - the effort to see the other from the inside. Affect regulation is keythe ability to recognize an emotion in oneself and pause momentarily before reacting so that attention to the other is not sidelined. These qualities tend to be present in those who are good listeners.

Medical education has evolved significantly in the past 30 years in its attention to communication as a core clinical skill. Yet, there has been less attention on how to listen and be present than to find the right words to say. The challenge of shared mind includes honing these listening skills-listening to others and to oneself-in the service of healing. This capacity can be enhance through contemplative practices such as meditation, structured dialogues, and other practices that promote listening and discernment. ${ }^{13-15}$ Fortunately, there are a growing number of opportunities for health professionals and trainees to get such trainng ${ }^{16,17}$ (see www.mindfulpractice.rochester.edu for further information).

\section{Ronald M Epstein MD.}

Professor of Family Medicine, Psychiatry, Oncology and Medicine Director, Center for Communication and Disparities Research University of Rochestere Medical Center 1281 South Avenue, Rochester, NY 14620 USA

ronald epstein@urmc.rochester.edu www.ronaldepstein.com 


\section{Bibliografía}

1. Glouberman S, Zimmerman B. Complicated and Complex Systems: What Would Successful Reform of Medicare Look Like? In: Forest P-G, Marchildon GP, Mclntosh T, editors. Romanow Papers: Changing Health Care in Canada. 2: University of Toronto Press; 2002.

2. Zlatev J, Racine TP, Sinha C, Itkonen E. The shared mind: Perspectives on intersubjectivity. Amsterdam/Philadelphia: John Benjamins Publishing Co; 20082008.

3. Meegan SP, Berg CA. Contexts, functions, forms, and processes of collaborative everyday problem solving in older adulthood. International Journal of Behavioral Development. 2002;26(1):6-15.

4. Epstein RM. Whole mind and shared mind in clinical decision-making. Patient Education \& Counseling. 2013;90(2):200-6.

5. Epstein RM, Gramling RE. What Is Shared in Shared Decision Making? Complex Decisions When the Evidence Is Unclear. Medical Care Research and Review. 2012;70(1S):94-112.

6. Epstein RM, Street RL, Jr. Shared mind: communication, decision making, and autonomy in serious illness. Annals of Family Medicine. 2011;9(5):454-61.

7. Epstein RM, Peters E. Beyond Information: Exploring Patients' Preferences. JAMA: The Journal of the American Medical Association. 2009;302(2):195-7.

8. Siegel DJ. The mindful brain: Reflection and Attunement in the cultivation of well-being. New York: W.W. Norton; 20072007.

9. Epstein R, Entwistle V. Capacity and Shared Decision Making in Serious Illness. In: Quill T, G. MF, editors. Palliative Care and Ethics. New York, NY: Oxford University Press; 2014.

10. Mazer BL, Cameron RA, DeLuca JM, Mohile SG, Epstein RM. "Speaking-for" and "speaking-as": pseudo-surrogacy in physician-patient-companion medical encounters about advanced cancer. Patient Educ Couns. 2014;96(1):36-42.

11. Entwistle VA, Carter SM, Cribb A, McCaffery K. Supporting patient autonomy: the importance of clinician-patient relationships. J Gen Intern Med. 2010;25(7):741-5.

12. Bartels J, Rodenbach R, Ciesinski K, Gramling R, Fiscella K, Epstein R. Eloquent silences: A musical and lexical analysis of conversation between oncologists and their patients. Patient Educ Couns. 2016;99(10):1584-94.

13. Beckman HB, Wendland M, Mooney C, Krasner MS, Quill TE, Suchman AL, et al. The impact of a program in mindful communciationon primary care physicians. Academic Medicine. 2012;87(6):1-5.

14. Krasner MS, Epstein RM, Beckman H, Suchman AL, Chapman B, Mooney CJ, et al. Association of an Educational Program in Mindful Communication with Burnout, Empathy, and Attitudes among Primary Care Physicians. JAMA. 2009;302(12):1284-93.

15. Epstein RM. Attending: Medicine, Mindfulness, and Humanity. New York, NY: Scribner; 2017. 
FOLIA HUMANÍSTICA, Revista de Salud, ciencias sociales y humanidades Nº 6, junio-julio 2017.ISSN 2462-2753

16. Dobkin PL, Hutchinson TA. Teaching mindfulness in medical school: where are we now and where are we going. Medical Education. 2013;47(8):768-79.

17. Hassed C, de Lisle S, Sullivan G, Pier C. Enhancing the health of medical students: outcomes of an integrated mindfulness and lifestyle program. Advances in Health Sciences Education 2009;14(3):387-98.

Cómo citar este artículo: Epstein, R. M., "Shared Mind", en Folia Humanística, 2017; 6: 1-8. Doi: http://dox.doi.org/10.30860/0025.

(C) 2017 Todos los derechos reservados a Revista Folia Humanística de la Fundación Letamendi Forns. This is an open access article. 